\title{
Childhood Angiosarcoma
}

National Cancer Institute

\section{Source}

National Cancer Institute. Childhood Angiosarcoma. NCI Thesaurus. Code C9174.

An angiosarcoma occurring in childhood. 